BIOÉTICA PARA PROFISSIONAIS DA SAÚDE. Rego S, Palácios M, Siqueira-Batista R. Rio de Janeiro: Editora Fiocruz; 2009. 160 p. (Coleção Temas em Saúde).

ISBN: 978-85-7541-182-7

\section{Bioética e Saúde Pública}

A bioética encontra-se em um momento de vigor no Brasil. Os anos 1990 marcaram os seus passos iniciais: o surgimento de grupos de pesquisa vinculados a programas de pós-graduação em saúde pública, as primeiras publicações em língua portuguesa e a criação da Sociedade Brasileira de Bioética. Já a consolidação da bioética nas universidades como um novo campo de conhecimento e pesquisa é resultado da última década 1 . Há disciplinas de bioética para a graduação em quase todas as universidades públicas brasileiras e alguns programas de mestrado e doutorado, além de diversas linhas temáticas em programas afins, como de filosofia, política social ou direito. Esse novo cenário provocou o mercado editorial sobre como responder a um público crescente, porém muito diversificado.

A obra Bioética para Profissionais da Saúde atende a uma parcela significativa dos leitores interessados em conhecer a bioética. Seu objetivo é apresentar a bioética para profissionais de saúde, uma idéia ao mesmo tempo ousada e simples. Se, por um lado, é difícil perseguir a originalidade quando se assume a tarefa de resumir um campo para leitores neófitos, por outro, esse é sempre um exercício à espera de ser feito, ainda mais em áreas tão interdisciplinares quanto é a bioética. Nesse sentido, o livro cumpre com o que promete: de fácil leitura, é um convite à reflexão, ampliando as fronteiras do pensamento para quem tem o dever de exercitar a dúvida em situações como as provocadas pelo aborto, por exemplo, em que as crenças religiosas dos profissionais de saúde costumam se sobrepor aos deveres de assistência em saúde. Há, no entanto, certa redução da categoria dos profissionais de saúde aos médicos, talvez uma marca cega da inserção disciplinar dos três autores.

Mas a aposta dos autores é que a reflexão bioética deve ser exercitada por todos os profissionais de saúde e não apenas por aqueles que venham a se definir como "bioeticistas". Como outros saberes, a bioética se ensina e se aprende em diferentes níveis de profundidade, mas há um nível para o qual, sustentam os autores, todos os profissionais que se confrontam com os desafios impostos pelo cuidado e pela gestão da saúde devem estar sensibilizados. O livro é, portanto, uma ferramenta de suporte para o ensino da bioética a esse público tão diverso. Nesse sentido, é uma peça útil não apenas para os que ainda estão em formação, mas também para professores, preceptores em hospitais ou membros de comitês disciplinares, a quem a obra oferece um mapa seguro das ferramentas básicas do campo.

Talvez por ser um campo tão aberto e com múltiplas fronteiras disciplinares, os autores não definem a bioética. A opção foi por apresentá-la por seu objeto de pesquisa e espaço de atuação, mas não por meio de conceitos. Para o público almejado, essa pode ser uma estratégia eficaz, pois aproxima os leitores pela experiência e não pela abstração da teoria. No entanto, essa é uma ausência que rapidamente se percebe no capítulo Bioética: História e Conceitos, onde os autores apresentam um miniglossário de palavras-chave do campo. Conceitos como direito, religião, ética ou moral foram apresentados como ferramentas de trabalho e, assim, resumidos aos limites de um parágrafo. Somente a recepção da obra mostrará aos autores a eficácia dessa estratégia para um público cujo fôlego de leitura é reduzido e que provavelmente terá na obra um manual de boas práticas.

O livro tem um movimento próprio: combina de maneira interessante a história da bioética com casos e múltiplas estratégias de reflexão conceitual, além de exemplos concretos das realidades brasileira e internacional. Esse ritmo entre a realidade e as ferramentas conceituais é uma fortaleza da obra, em particular porque permitirá aos professores sempre atualizarem o repertório de realidade a ser explorado com seus alunos. Há, no entanto, momentos em que o estilo narrativo do livro oscila entre um esforço pedagógico e um excesso de informações, como se fossem diferentes vozes assumindo a autoria das seções. Esse, na verdade, é um traço característico de obras com autorias compartilhadas, em particular entre autores cuja inserção em um determinado campo já é bastante definida.

Por fim, uma questão merece destaque, muito embora talvez os operadores do direito não sejam o público-leitor da obra: os autores vêem de maneira pessimista a aproximação entre a bioética e o direito. Não há dúvidas de que a bioética cresce vertiginosamente entre a nova geração de juristas. Se, por um lado, são os profissionais de saúde que experimentam cotidianamente grande parte dos conflitos morais da bioética, por outro, são os operadores do direito que são confrontados não apenas com essas mesmas questões, mas com o desafio adicional de responder a elas rapidamente e com a força do Estado.

Curiosamente, a compreensão dos autores sobre esse encontro, que pode ser revigorante para a bioética brasileira, não é estimulante para os leitores. O direito se confunde com as normas e leis instituídas, isto é, com uma mera aplicação da ordem estabelecida aos 
conflitos morais. Os autores reconhecem que questões decisivas à bioética brasileira foram enfrentadas nas cortes e tribunais, mas se recusam a dar o devido sentido a essa aproximação. Temas como a pesquisa com células-tronco embrionárias, a anencefalia, a cirurgia de mudança de sexo ou a judicialização do acesso à saúde foram provocados nas cortes e é nelas também que a reflexão e a argumentação em bioética avançam. E esse parece ser mais um intenso movimento de revigoramento da bioética para a próxima década no Brasil.

Debora Diniz

Universidade de Brasília, Brasília, Brasil.

Anis - Instituto de Bioética, Direitos Humanos e Gênero, Brasília, Brasil.

1. Braga KS. A comunicação científica e a bioética brasileira: uma análise dos periódicos científicos brasileiros [Tese de Doutorado]. Brasília: Programa de Pós-graduação em Ciência da Informação, Universidade de Brasília; 2009. 